\title{
The Acting Class and the Myths of Meritocracy
}

\begin{abstract}
Our feature documentary The Acting Class (2017) is here contextualised in the context of a critique of the cultural industries as part of the ideology of meritocracy and a resurgence of work around class in the sociology of culture. The Acting Class focuses on the question of class stratification in the UK acting industry. We here review our research on this issue and contextualise it within the scholarly literature on diversity and inequality, the creative industries and the broader re-configurations of the political economy of British capitalism. We also discuss the importance of the interview in creative practice research as a way of democratising knowledge production and socialising experience.
\end{abstract}

Keywords: Meritocracy, acting, class, culture industries.

\section{Introduction}

In this essay we wish to reflect on how our creative practice-based research in the form of the documentary genre, was used to investigate and critique the ideology of meritocracy as it impinges on working-class origin actors struggling to carve out careers in the UK acting industry. Our documentary feature film The Acting Class (Deirdre O’Neill \& Mike Wayne 2017) ${ }^{i}$ is contextualised within a resurgence of work around class in the field of the sociology of culture. Sociology is reconnecting with the issue of class after a long period of academic disengagement aligned with what Ellen Meiksins Wood identified as the 'retreat from class' as early as the mid 1980s (Wood 1998). This re-engagement was initially spurred by New Labour governments' framing of the cultural industries within a meritocratic 'opportunities for all' ideology. The 'return to class' research agenda then accelerated following the 2008 global crash when many of the delusions of mainstream policy makers ('no more boom and bust' as Chancellor of the Exchequer Gordon Brown once proclaimed) were cruelly exposed. This academic re-engagement was also broadly focused on the cultural industries and scholars interested in policy and political economy around the film and television industries have contributed to this debate, not least in the pages of this journal (see the special issue on diversity in volume 17 (1) January 2020). But the sociology of culture tradition has also included work specifically on working-class origin actors and the barriers to entry they face. It is through 'acting' rather than 'stars' that the class discriminations of this 
form of cultural labour as a collective problem are best addressed. In the case of Britain, with its long-established strategies of social class reproduction, the barriers and discriminations are considerable. The interest in acting and class shown by cultural sociology can be usefully cross-fertilised with more discipline specific acting studies. Both share at least one important methodological approach: the interview. In theatre studies and recently in television drama studies, the study of acting has gone beyond what Richard Hewett calls the "purely immanent readings' of texts (2015) that have dominated the analysis of (typically inaccessible Hollywood) stars. By engaging with (more accessible) television practitioners through the semi-structured qualitative interview, (including directors working with actors (Cantrell 2018)) researchers can access the reflective knowledge which creative labour has of the craft of acting (Cantrell and Hogg 2016) and of immediate production processes and broader contextual factors and trends (Hogg 2020). Likewise The Acting Class is an example of creative practice research that depends fundamentally on interviews with actors (primarily) and their thematic re-presentation/re-organisation within the documentary genre. Here we contextualise our film on the intersection of class and acting within the scholarly literature on diversity, the creative industries and the broader re-configurations of the political economy of British capitalism.

\section{New Labour, Culture and Meritocracy}

Meritocracy can be defined as an ethos of individual freedom, just rewards based on hard work and talents and the idea of social mobility unconnected to class origins, triumphing over barriers whose structural roots are disavowed. Meritocracy was central to both Margaret Thatcher's brand of conservatism in the 1980s and Tony Blair's brand of social liberalism during the period of New Labour governments between 1997-2010. These are distinct repertoires of neoliberalism, the former invested in a strongly ethnically exclusive nationalism plus consumerism, the latter promoting itself as a more inclusive, multicultural and therefore more authentically meritocratic politics (Littler 2018: 87). It is no surprise then that Prime Minister Tony Blair made both meritocracy and the cultural industries central to the political discourse of New Labour in government. 
If industry had once constituted a significant social base of support for Labour, linking it to the working-class, de-industrialisation, especially in the north of England and Scotland, has depleted the political and economic connections between the party and traditional class orientations (something that was confirmed in the December 2019 General Election where long held Labour seats in the north swung behind the Conservative party). The cultural industries allowed New Labour to retain a commitment with at least some diminishing base of manufacturing, while providing a public relations dazzle to a political discourse keyed into the promotion of 'New' Britain in international image markets (film, television, advertising, music, etc). Where Labour once placed the working-class at the centre of its ethical-political vision, it's preferred agent of history was now somewhat different: a tiny, upper middle-class strata of 'talent' and executives (Wayne 2018: 174-80).

It was assumed that prioritising conventional capitalist economic priorities would not contradict New Labour's 'opportunities for all' social justice ambitions. In general, the main enemy against opportunity for New Labour was not the kind of social-class inequalities the left has traditionally associated with capitalism, but social liberalism's favourite targets associated with conservatism, such as 'privilege', 'snobbery', 'intolerance', lack of 'open mindedness' and lack of educational routes to self-improvement. 'I make no apologies', wrote Blair, 'for wanting Britain to be a nation characterised by merit, not privilege or stuffiness' (Blair 2001: 55). A war on 'stuffiness' (old fashioned upper middle-class notions of decorum) did not require a critique, much less an attack on the political economy of late capitalism.

Since the word 'culture' still retained connotations that transcended the priority of exchange value, it was often coupled with or displaced in New Labour discourse by the word 'creativity'. Blair again: 'The next century will be dominated by brain, not brawn. Creativity and knowledge will be the key tools. And Britain has always been a world leader in creativity and innovation' (Blair 2001: 53). As Toby Miller noted, the concept of creativity shifts the focus towards process and inputs rather than what is actually produced, a 'bizarre shift in adjectival meaning [that] makes it possible for anything that makes money to be creative' (Miller 2009: 95 emphasis added). Thus the creative industries were increasingly seen by policy makers and think tanks, as the 'blueprint for a new form of post-industrial economy' (O'Brien, Laurison, Miles and Friedman, 2016: 117). The highly 'flexible' labour markets in the US and UK film industries for example were seen as pointing the way forwards to a 
future of precarious employment (Blair 2001), but one that should be embraced for its 'positives'. Creativity became a code word for developing 'the competitive functions of individual human capital' (Cultural Policy Collective 2004: 11).

These policy and political discourses re-packaged job insecurity (the end of a job for life) as part of an exciting and dynamic environment where workers embarked on 'portfolio' careers and within any one career lived on their wits as risk taking freelancers moving from project to project. The realities of job insecurity could be glossed over by imbuing this carefully constructed political economy, founded on the radical diminishing of trade union power through changes in working practices and legal constrictions, with a moral and cultural hue drawn from the romantic narratives of rebellion associated with the bohemian life of the artist that stressed autonomy, authenticity, self-expressiveness and a general libertarianism (McGuigan 2009, Ross 2010, Boltanski and Chiapello 2018).

By the end of the New Labour period in office in 2010, the academic verdict on the realities of being a cultural worker was in and it painted a less rosy picture of working conditions than the policy makers and think tank advocates of the new economy (Banks and Hesmondhalgh 2009). The emphasis on self-reliance, ambition, competition and 'talent' at the expense of workplace protection and rights disguised exploitation, 'self-exploitation' (where workers willingly overwork because they are 'passionate' about the job) and under-employment (McRobbie 2011: 41; Blair 2001). Sustaining a career has become much harder for the real 'creatives', becalmed by shrinking wages and stressful casualised working conditions, than for the management types cutting costs and making employment decisions (McGuigan 2010: 330). Hopes that the creative industries could drive regional economic growth and solve a wide range of other social problems, relied on a growing gap between rhetoric and evidence base (Oakley 2011,) or what Belfiore described as 'bullshit in cultural policy practice' (2009). Meanwhile the notion that the cultural industries were themselves examples of social mobility was contradicted by the under-representation of women, ethnic minorities and the working-class in the workforce generally as well as in senior decision-making positions (Oakley 2011 and Littler 2018: 161). Drawing on Labour Force Survey data for example, Friedman and Laurison found that in film and television the general workforce had around half of the proportion of working-class people in it than in the workforce as a whole. Engineering or senior jobs in the emergency services did significantly better in terms of 
proportionate working-class representation than the much more vaunted and high esteem culture industry (Friedman and Laurison 2019:33).

\section{Neoliberalism and the era of Austerity}

Following the 2008 global crash New Labour lost its ideological lustre but the limited range of alternative political possibilities was all too evident when a new Conservative-Liberal Coalition government formed power between 2010-15, followed by successive Conservative governments (2015-17, 2017-2019, 2019-to the present). This period saw the rise of austerity as the political-policy response to the economic crisis. This meant substantial cuts in public services and to local municipal authorities, with nearly 800 libraries closing between 2010-19 (Busby 2019) and 26 per cent cuts on average to local authority spending under the Conservative-Liberal Democratic coalition (Blackburn 2018: 9). One of the first things the Conservative-Liberal government did was to build on New Labour's introduction of individualised fees for Higher Education students, ramping up costs to around $£ 9,000$ per year. The expansion of programmes in media, film, television, culture and the performing arts under the New Labour's boosterism of the 'creative economy' could now only be accessed by incurring high levels of personalised debt (including maintenance loans for students). Austerity resulted in the longest and deepest cuts in real wages since the Napoleonic wars in the early part of the nineteenth century (Tily 2018). Within months of taking office, the Coalition government's Comprehensive Spending Review, which prioritised deficit reduction plans, spelt out cuts of between $15 \%$ to $30 \%$ in major cultural institutions such as museums and galleries, the British Film institute and the Arts Council (Newsinger 2015: 306).

In this context of increasing hardship, the importance of class began to make a welcome return in not only academic research but also popular publications. The cultural industries and in particular the acting profession in the UK seemed to be a lightning rod for concerns in the popular press about the impact which inequality was having on some of the cherished illusions of meritocracy. A number of reports in the popular press focused on the potential consequences for the performing arts when working-class origin actors were finding it increasingly difficult to sustain careers in the sector. Established working-class actors who had entered at a time when there was greater support (such as grant supported education) in particular were sounding the alarm. 
There are three main reasons why the accessibility of the acting profession to a wide range of people, in class, gender and ethnic terms, is important.

1) There are social justice considerations, namely why should a profession be largely monopolised by a particular group while others find themselves significantly underrepresented within it? This social justice consideration concerning participation can be extended to questions of degree, such as how success within a career is unevenly distributed according to class origins, for example in terms of a class pay gap (Friedman, O'Brien and Laurison 2017). There is also evidence that working-class origin actors struggle to escape narrow class defined typecasting (Friedman and O'Brien 2017) and so have less opportunities for a fulfilling career. We may also note in relation to the intersection between class and ethnicity, that as Randle et al note, '[o]ften absent from the diversity agenda is the question of social class' (Randle, Wing-Fai, Kurian 2008: 9). Yet given that some ethnic groups, such as those from Pakistani, Bangladeshi and Black, African and Caribbean background are firmly located in the lower socio-economic classifications (Francis-Devine 2020), it seems likely that addressing class diversity should be an important co-variable in addressing questions around ethnic diversity.

2) There are economic considerations for the industry. An overly homogeneous composition of creative talent is likely to struggle to innovate its product offering and find new audiences and markets. Within the ecology of the performing arts, actors play a crucial role for other creative workers, such as directors and writers. The Warwick Commission's recent report found that children born into low income families were the least likely to find successful employment in the cultural and creative industries, and yet 'diversity is essential to the future success' of those industries (Neelands 2015: 14-15).

3) There are broader issues connected with national identity and ideology at stake. The performing arts tell stories that implicitly project images of the collective, their history, identity, who they are, what they look like, how they speak, what they value, who has esteem and so forth. If the acting profession is drawn from a narrow range of social groups, if there are limited opportunities for working-class or black actors for example, then that is likely to shape the kinds of stories the cultural industries produce and the kind of angles from which 
those stories are told resulting in a lack of alternative perspectives, knowledge and experiences.

The British film and television industries for example has long projected a certain white aristocratic heritage identity in international image markets, especially for the American market (Wayne 2006). Raising barriers for working-class origin actors will only reinforce this historic trend. In the BFI document Opening Our Eyes, How Film Contributes to the culture of the $U K$, it is very clear that audiences value 'realism' as a broad aesthetic ambition. Over $40 \%$ of respondents in Scotland, Wales and Northern Ireland thought that too many films were located in London and the home counties and featured rich and privileged characters (BFI 2011: 40). For them, realism was associated with a class profile closer to their own experience. Does this have any connection with the social-class background of the actors themselves? Leaving aside for the moment the social justice question, we can say that there is no necessary correspondence between class background and actor ability to play a diverse range of roles. For example Tom Hardy comes from a privileged background and yet plays ordinary and working-class characters with aplomb, as in the BBC's Peaky Blinders (2013 - ) series where he plays a working-class Jewish gangster from London or the feature film Legend (2015) where he played both of the Kray twins. Similarly Ralph Nathaniel TwisletonWykeham-Fiennes comes from a upper class social background but has the acting talent to play a working-class auto-didact with great conviction in The Dig (2021). However, if the critique of meritocracy has value then we would expect (hypothesise) that opportunity hoarding would result in actors being successful who do not have the talent to transform themselves in the ways required to 'undo' the deep social, psychological, even physical conditioning of the actor's body which social class produces (Bourdieu 2000: 118; Manstead 2018). Therefore a lack of diversity in the class origins of actors is likely to reinforce already powerful tendencies (the lure of the American export market for example) towards a certain white middle class, South-East profile to the construction of a national identity that is out of kilter with popular tastes.

\section{Class and Education}


The Acting Class demonstrates the interaction of multiple and cumulative barriers for working-class origin actors including: financial inequalities, the unequal distribution of social and cultural capital, the importance of networks and support groups, the London-centric nature of the business, the precarious nature of the work, class discrimination in casting, the wider political context in which a homogenisation of talent entering the industry takes place and the possible impact which these barriers have on representation and storytelling. These issues constitute the thematic clusters around which the film is organised.

A report by the Social Mobility and Child Poverty Commission found that the $7 \%$ educated at private schools dominate disproportionately the higher echelons of such professions as the judiciary, politics and the media (Milburn 2014: 12). There is a strong myth within the performing arts and within the acting profession generally that the sector is somehow exempt from such structural elitism. The 'Holy Trinity' that hard work, talent and good luck are the main determinants in shaping opportunities and outcomes is prevalent. But education at a private fee-paying school would also seem to be as important given the over-representation of the privately educated in lead roles and awards. Research by the Sutton Trust provides some evidence that this is also true of the acting profession as well. In film, $42 \%$ of the British winners of the main British Academy Film and Television Awards (BAFTA) attended private fee-paying schools (Kirby 2016: 2). Our own research found that in 34 out of 58 films, the first lead role in the top British films at the UK box office between 2014-16 were privately educated (59\%). In only 24 out of 58 films, was the first lead role in the top British films at the UK box office between 2014-16 state (and grammar school) educated (41\%). ${ }^{\text {ii }}$

The most famous private school for boys in the country, Eton (charging around $£ 35,000$ per year) has produced many star actors, including, recently Dominic West (The Wire - 20022008, Pride - 2014, Les Misérables - 2018-19 ) Damian Lewis (Band of Brothers - 2001, Homeland 2011-14, Wolf Hall -2015 - Once Upon A Time In Hollywood -2019) and Eddie Redmayne (The Good Shepherd - 2006, Les Misérables - 2012, The Danish Girl - 2015, Fantastic Beasts and Where To Find Them, 2016, The Trial of the Chicago 7 -2020). High profile, awarding winning female actors might not have the opportunity to attend Eton but Oliva Coleman, Kate Winslet, Rosamund Pike, Phoebe Waller-Bridge have all been educated in the private sector. The three leads of the BBC television spy drama The Night Manager (2016), Tom Hiddleston (later to play Loki in Thor and Avengers movies), Tom Hollander and Hugh Laurie, were all educated at the same Oxford early years private school for boys 
and girls, known as The Dragon School. The place has also produced actors such as Emma Watson, Jack Davenport, Hugh Dancy, Dom Joly and Jack Whitehall (Ramaswamy 2016). As well as training, facilities, expertise and general encouragement in their ambitions, the private schools also provide high value social capital, those crucial networks of knowing the right people in important decision-making parts of the industry.

Although fully representative data sets regarding the class composition of actors in the UK is not available, sociologists have been able to analyse at least some survey data. The Great British Class Survey (2013) which was a self-selecting online survey produced by academics at the London School of Economics in collaboration with the British Broadcasting Corporation, generated data on 402 self-identified actors, while the Labour Force Survey includes a much smaller sample of 61 . Sociologists found that only $10 \%$ of actors from the GBCS came from working-class origins and only 16\% from the Labour Force Survey (Friedman, O'Brien and Laurison, 2016: 997), the latter again around half of the proportion of working-class workers in UK labour force, according to sociological classifications based on the occupations of parents.

The Acting Class begins with Tom Stocks, an aspiring young actor from Bolton, in the North of England, revisiting a London based acting school called East 15. It was here that Stocks was offered a chance to take a post-graduate Masters course in acting. However, the fees for the course was $£ 12,000$ and living costs (in London) would have required an additional $£ 6,000-£ 9,000$. Tom had already acquired a debt from his undergraduate degree which had been in a university setting where there is much less emphasis on professional practice. Standing in the grounds of East 17, Tom tells the audience that he tried to save the money for the one-year programme for over a year and a half, while working as a chef on a minimum wage. He was not able to do it. This spurred him to set up an organisation (Actor Awareness) dedicated to helping working-class actors with a support network and opportunities for putting on plays. Tom's own experience of being locked out of training was not unusual. The film also hears from Amy, a working-class young women from Liverpool, who was offered a place on a foundation course at another London based drama school, Italia Conti. Again she tried to raise the money for two years but in the end had to admit defeat: 'I felt a bit like I failed because I didn't have money, I didn't have thousands and thousands and thousands of pounds, to do that course for a year (10.50).' 


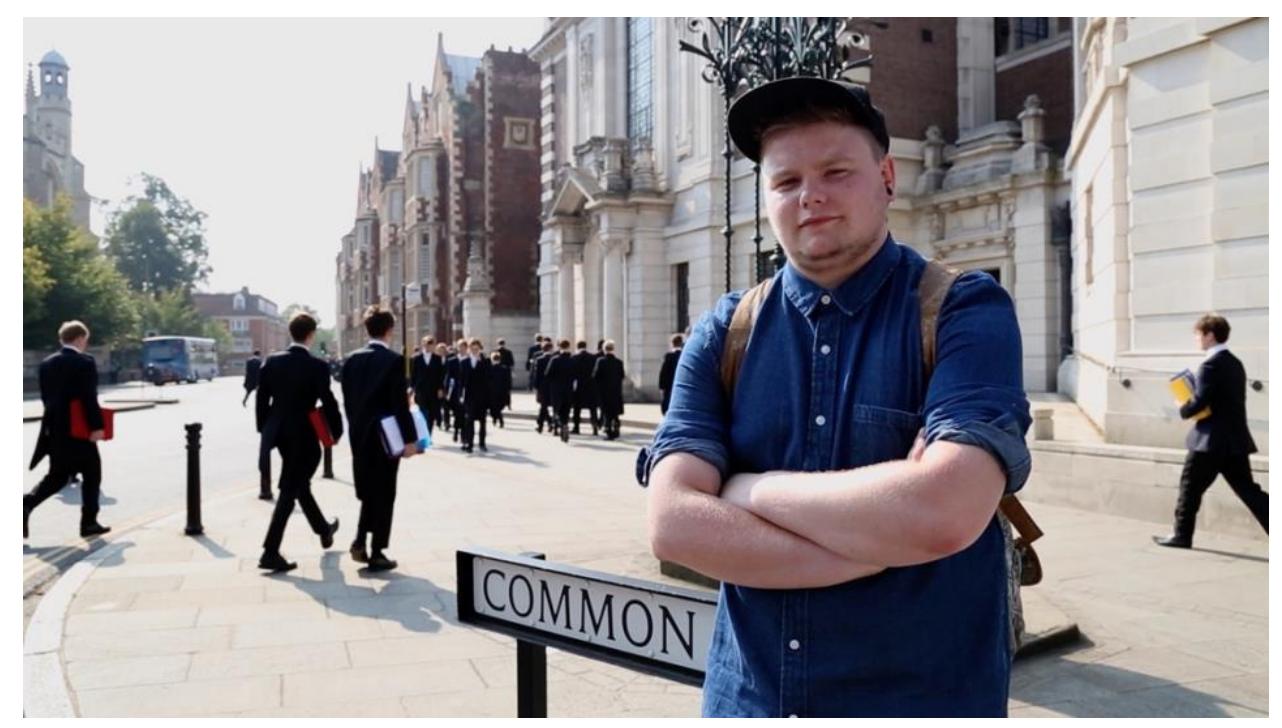

Tom Stocks visits Eton in The Acting Class

It is the relationship between the economic distribution of resources and other resources of culture, social networks and educational opportunities where the subtleties of class fixing and individual trajectories are shaped and formed. In the film Tom Stocks visits Eton to underscore the difference in opportunities which he and others like him have had compared to the privately educated. The sociologist Pierre Bourdieu did much to help our understanding of how class shapes responses to the environment and individual calculations of likely outcomes. 'It is the people in your own background', Maxine Peake observes, who are most likely to be telling would-be working-class actors that their aspirations are unrealistic. Bourdieu describes this as the formation of a habitus:

'the mental structures through which... [agents] apprehend the social world, are essentially the product of the internalization of the structures of that world' (Bourdieu 1989: 18). A realistic adaptation to one's position in the social structure brings expectations in alignment to objective probabilities.

The immediate social network of acquaintances and friends in a working-class mileux are also least likely to be able to offer advice - much less contacts in the business - about how to pursue this career path even if they are supportive in principle. Andrew Ellis talks of 'falling into' acting thanks to the inclusive casting practices of Shane Meadows for This is England, but otherwise, his life opportunities and knowledge would have been wholly shaped by the industrial estates or airport that provided most employment opportunities for his peers. Economic resources form part of a pattern of closely interrelated resources of cultural competences, social networks and educational qualifications that together shape the 
individual and their life opportunities. Julie Hesmondhalgh talks of the 'confidence' which the privately educated have that the world is their oyster, that it belongs to them and notes that that sort of confidence is not necessarily as easily available to 'a girl from Accrington' such as herself. Confidence is indeed one of the key attributes of the middle-class subjectivity or habitus, borne of an easy sense of entitlement, that the world is truly there to succeed in (Friedman and Laurison 2019: 23-7).

\section{Cultural Matching}

Drawing on interviews and ethnographic observation, Friedman and Laurison have explored how 'cultural matching' works to reproduce opportunities for the middle and upper middle class and diminish the importance of 'talent'. Cultural matching is based on the premise that 'similarity breeds connection' (Friedman and Laurison 2019: 214). The 'connection' can be as tight as being alumni of the top universities such as Oxford and Cambridge. As black working-class actor Elliot Barnes-Worrell puts it in The Acting Class:

The people at the top are all white middle class men or white upper class men, privately school educated. And then when they want to hire someone to work for them...they hire themselves. They go: 'you went to Cambridge, I went to Cambridge, we went to Cambridge, let's all be together $(31,43)$.

But this cultural matching also works more subtly through a broad range of cultural signs by which members of the same class recognise each other. Speech for example in the UK is strongly class coded, with Received Pronunciation, or RP the accent of the upper middle class. RP eradicates any regional specificities and instead pretends to a placeless 'universality' that is actually very class specific while simultaneously marking place specific accents as less than universal, coming from a somewhere that is coded with less esteem. RP plays an important role in the acting profession in the UK. It says something of the domination of the middle class across the panorama of the performing arts that as part of their drama school training, actors must master RP. But a number of working-class actors we spoke to noted that this was sometimes pushed even further within drama school. Julie Hesmondhalgh: 
There was a moment in my first year when I was encouraged to speak in RP outside the rehearsal room and outside the classroom, in order for it to become a natural way of speaking for me. And I weren't happy about that and I didn't want to do that and I know a few people who've had that... this voice is very much part of who I am and where I am from ...it's very tied in with who I am I didn't see the need for myself to pretend to be a different person as I went about my daily business (26.25).

The broader cultural validation of RP and the middle-class identity it expresses means that those who grow up in a different class, acquire a felt sense of inferiority and lack of confidence. The actor Christopher Eccleston brought out the implications of the hierarchy of esteem attached to accents in The Acting Class:

One thing that was really powerful to me as a child, whenever I heard a voice of authority, whenever I heard a voice that was 'intellectual', whenever I heard a voice that was 'cultural' it was white, it was male and it was middle class. Dialect is an important thing, if you sound like me and millions of other people like me from Scotland or Liverpool or wherever, you don't necessarily think that your accent denotes creativity or intellect. So you don't think you will play Hamlet. You think that the properties of being intellectual and poetic and soulful reside in an $\mathrm{RP}$ accent $(25,18)$.

The subtle adjustments of expectations to social position which forms the habitus is reinforced with the matching expectations that others, such as casting directors bring to employment opportunities. Hesmondhalgh has noted elsewhere that there is 'a pecking order of regional accents and comfortable TV casting associations'. While her Accrington accent has allowed her to play 'professional working-class' roles such as nurses and teachers, other accents (Liverpudlian, Midlands, etc) seem to disqualify actors from these roles in the minds of those with the power to employ (Hogg 2020: 304-5). Instead, as a number of actors note in our film, an actor from a working-class background will often struggle to get a role that implies a university level education. Yet, as Christopher Eccleston observes, middle class actors are allowed to 'act-down'.

\section{Geography and Class Inequalities.}


Some $43 \%$ of jobs in the cultural industries are located in London (Neelands $2015: 68$ ) and some $50 \%$ of the UK audio-visual industry is based there (Randle 2008: 21). Overall $71 \%$ of film companies are concentrated in London and the South East (BFI 2016: 246). The London-centric nature of the acting profession reflects broader economic imbalances. According to the sociologist Mike Savage, London contributed nearly seven times more to the national economy than Britain's second city, Manchester. 'This is an economic imbalance that has rarely existed in other nations or at other times in history' (Savage 2015: 267). Class therefore has a strong geographical dimension. One consequence of geo-class differences is that there is limited access to the creative industries outside of London with the consequence that often it is not seen as a wise career choice for young working-class people, one that would offer them any kind of financial security or long-term prospects. In our film, Osman Baig, from a working-class Asian background commented: 'When I was growing up in Bradford, the idea of doing theatre or acting just wasn't on the cards.' Added to this there is the on-going problem of self-exclusion with people from areas with limited opportunities for engagement in creative activity more likely to think they would not be taken seriously as 'creatives' (Allen and Hollingworth 2013).

Attachment to the place where one grew up and where family and friends reside is often seen as regressive and defeatist - suggesting immobility and a lack of entrepreneurial zeal (Skeggs 2004). But as educationalist Diane Reay found when researching why working-class students prefer universities closer to home even when they are not high status - place, feelings of belonging and familial attachment are important to the working-class in ways that do not apply to the middle-class mind-set that has been trained from an early age in competitiveness and individualism (Reay 2001). Two of the interviewees in the film illustrate this difference. Andrew Ellis was quite clear that his attachment to place and family was of equal importance to him as his career. He did try and live in Essex for a while but the financial cost and social loneliness meant that he moved back to Salford. Another interviewee, Rosie Woods, when reflecting on whether she should move to London to enhance her career prospects, commented that she was 'very northern' and that she did not want to become 'just a product' of someone or something else. The idea that the answer to regional inequalities is for people to move rather than to geographically redistribute resources only reinforces inequalities. 
The concentration of resources and opportunities for the acting profession in London -itself a hugely expensive part of the country to live in - reinforces exclusion mechanisms already built into the acting profession. In today's neo-liberal economy of flexible exploitation, it is quite rare to have a long-term contract (long running serials being the major exception for those whose characters become an established fixture in the story lines). Most acting work is built around relatively short-term projects which makes the work profession highly precarious. In the early years there may be considerable gaps between employment. Middle class origin actors however can call upon 'the intergenerational gifting of capital, either 'in vivo' or through inheritance' (Friedman, O’Brien and Laurison 2016: 1000). More colloquially, the former is known as the 'Bank of Mom and Dad' - a form of financial patronage that is particularly important in the context of elite precarious labour providing early career support, financial cushions, to take risks, develop networks (such as on-going workshops with casting directors) and not necessarily have to take non-acting jobs to pay for essentials such as rent and food and therefore to be available for auditions that often come in at very short notice. This private safety net allows the privileged to stay in this highly precarious sector longer waiting for the prize of sustained continuous work (Friedman and Laurison 2019: 90). In The Acting Class, Teddy Rose, brought out the deeper existential anxieties which this lack of economic and social capital (networks) has for the working-class actor:

The working-class actors that I have been around and that I have studied with and worked with and have grown up with; they fall off the map because every year that goes by they think 'oh no, I am that one year older, and money starts to become far more important. As working-class actors, if we don't make it, then we are screwed. We commit everything we have to potentially becoming actors, we don't have family members who could potentially provide us with a good job if it all falls through or they know someone who knows someone who can employ us if it doesn't work out for us. So they can try it for a few years and it all goers under, and they are still employed elsewhere. For us, it's a case of if we don't make it as actors, and we have committed everything we have to becoming actors, we have nothing to fall back on. We don't have a safety net $(18,40)$.

No wonder that sociologists have called the gradual filtering away of working-class acting talent a 'leaky pipeline' (Labour Party 2017:5). 


\section{On Creative Practice Research}

As a methodology, recorded interviews arranged in a creative-practice genre such as a documentary film is an excellent example of the strengths of qualitative research. Auerbach and Silverstein define qualitative research as able to 'discover meaningful patterns descriptive of a particular phenomenon' (Auerbach and Silverstein 2003: 3). But this does not seem specific enough as statistical methods also discover meaningful patterns in phenomena. What distinguishes qualitative research is the discovery of meaningful patters that are context sensitive, variable, complex, contradictory, nuanced, individuated and rich in their patterning. Good interviews across a range of speakers can cumulatively be all of those things. When arranged in thematic clusters, audio-visual interviews have two advantages over more conventional written scholarly research. Firstly it allows the subjects of the research much greater scope to articulate their own experiences and reflections on their own experiences directly to a viewer (Byrne 2018). Creative practice methodologies such as the documentary film, allow academic research to give more space to the research subjects than academic writing typically does. The importance of working-class self-representation (O'Neill 2018) adds a further layer to the politics of democratising knowledge production by validating experience, a category which at one point in the history of cultural theory, was held to be irredeemably ideological (Wayne 2020: 65-7). What is striking in The Acting Class is the analytical astuteness with which these subjects speak of their experience, the attitudes of class discrimination they have come across and sometimes internalised and the emotional power conveyed to the watching audience as to why this matters as a social justice issue, an emotional power generally absent from more conventional modes of academic discourse where 'objectivity' is much prized. Even where interviews are extensively reproduced in the academic literature, the audio-visual language of film provides a much richer range of communicating signs than the words on the page. Gesture, clothes, facial expression, voice, accent, intonation and so forth all provide important class and other related signs that interact with the content of the words. The emotion in Amy's voice as she recalls turning down an offer at drama school, the ironic smile on the face of Elliot Barnes-Worrell as he talks about Cambridge matching or the controlled anger of Christopher Eccleston through-out his interview, are all embodied in ways that really need to be seen and heard to be fully appreciated. 
Another important point is that the arrangement of voices in thematic clusters is crucial in socialising the experiences that individuals are relating; that is it excavates the common situation and constraints which individuals are confronted with. This is very important because in the age of neo-liberalism and meritocracy, the social conditions, the structural constraints, the shared problems, are always individualised and turned into challenges and opportunities: the former is a problem against which the moral worth of the individual can be tested, while the latter refers to the rewards available for those individuals who are talented enough and determined enough to overcome their problems. This is a very brutal ideology designed to make people think they ultimately are responsible for where they have ended up in life. If their hopes remain unrealised, the ideology of meritocracy teaches them that it is because they did not have the 'drive' or the 'talent' to succeed.

This socialisation of experience produced by the work of editing is reinforced by the public nature of the film's dissemination in a series of screenings which were also coupled with a campaign element. The film premiered in September 2017 at the TUC's Congress House where more than 100 people turned up and participated in the Q\&A afterwards that included Tom Stocks and an Equity representative. For us, the working-class improves its conditions when it organises through trade unions and political parties, so it was symbolically and practically important that the film's critique of meritocracy was made efficacious by speaking to and through trade unions as a crucial part of our praxis philosophy. The film screened at Equity branches in Oxford, Newcastle, Liverpool, Brighton and Sheffield and played a key role within Equity in helping push the question of class up the union's agenda and in the 2019 establishment of a new 'Class network' within the union. All in all, The Acting Class been screened publicly on more than 40 occasions followed by Q\&As. 


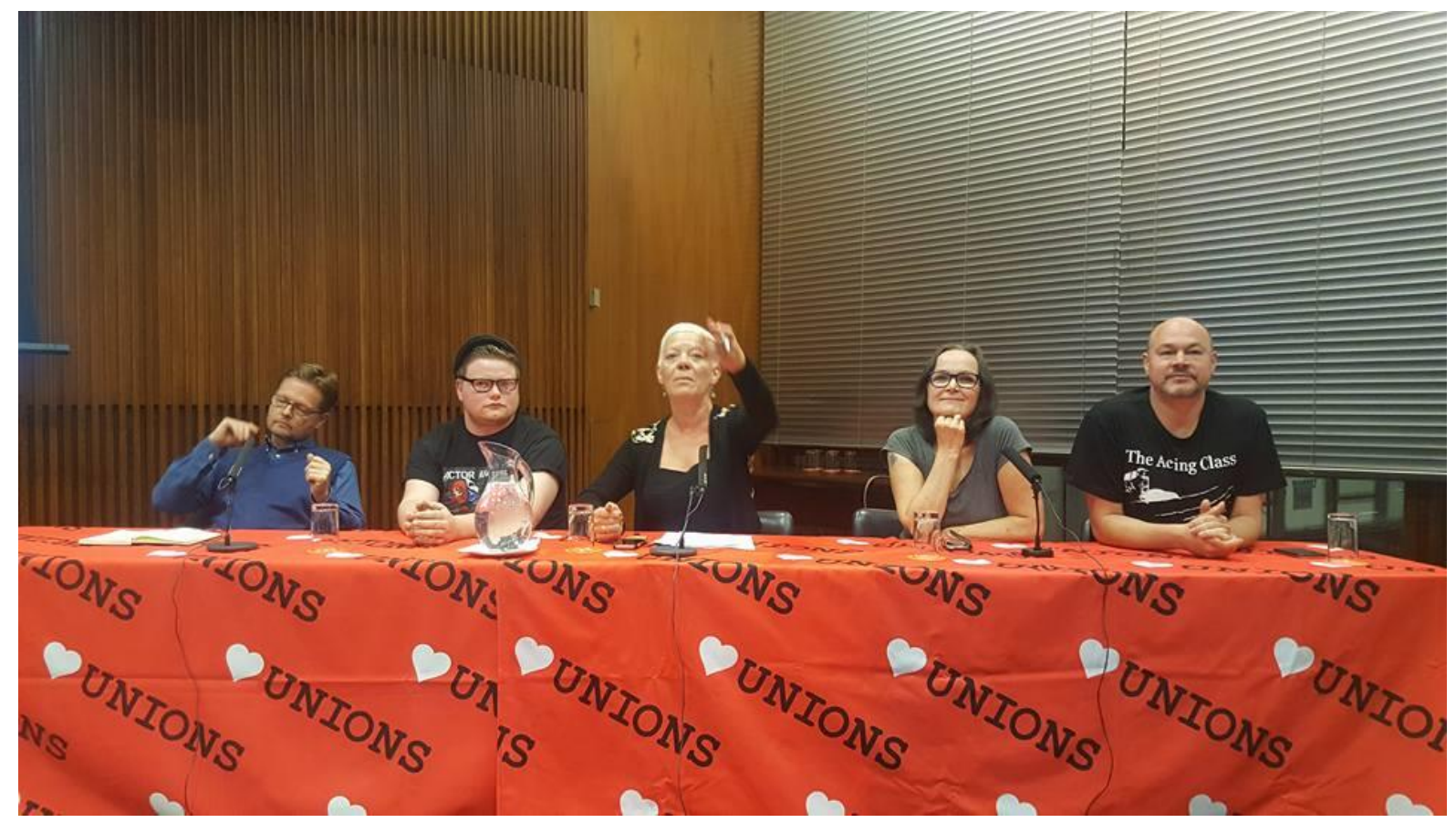

Megan Dobney (centre) regional secretary of the South East region of the Trade Union Congress chairs the Q\&A at the premiere of The Acting Class, with (from left to right) David John (Equity), Tom Stocks (Actor Awareness) and directors Deirdre O’Neill and Mike Wayne.

The impact of the film for individual actors was that it helped socialise experiences often perceived and/or felt to be their own individual problem or fault (as per meritocratic/neoliberal ideology). Post Q\&A tweets below after the screening in Newcastle at the Northern Stage, gives a flavour of the desire to see the issue addressed within the cultural industries and how the film provided a forum for collective discussion on a social problem unrecognised by the ideology of meritocracy. Creative practice-based research which is cast in the idiom of already existing genres such as the documentary film, has the potential for wider public reach and stimulation of conversations that are much less likely to happen when research is in the form of conventional academic discourse, especially in a UK context where the figure of the 'public intellectual' is barely recognised by the media and public alike. These are important tactical considerations in challenging dominant ideological formations. 
Blowin' A Hooley Blowin' A Hool

Brilliant night @northernstage to discuss @actingclassdoc Let's work together \& keep shouting to change the landscape for \#workingclass \#actors and \#artists in a hugely elitist industry @actorawareness @Tom_Stocks @AMarkCalvert

\#realpeoplerealstories \#theatre \#film \#performance

7:26 AM - 7 Feb 2018

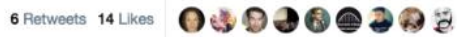

Demi Paradise TC @demiparadiseTC . $3 \mathrm{~h}$

Thank you @EquityUK for the invite to view @actingclassdoc + Q\&A Onorthernstage last night; honest, well argued polemic everyone in our business needs to hear \& support...Good luck to all at @actorawareness for making change happen.

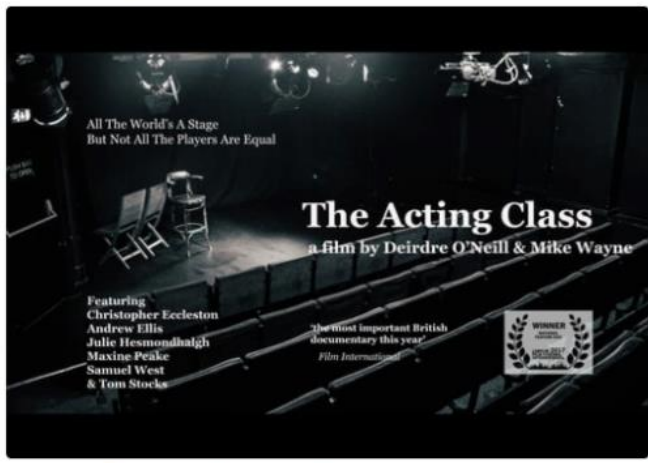

(1) Harriet Ghost Sharrietghos

Great to see @actingclassdoc \& important discussion @northernstage Keep the conversation going @Tom_Stocks \#actorawareness \#workingclass \#timeforchange \#northeast \#uk \#theatre \#actorslife

3:51 PM - 6 Feb 2018 from Wallsend, England

5 Retweets 9 Likes
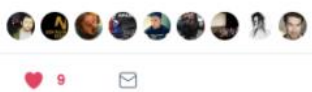

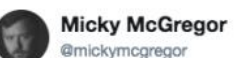

Imickymogregor

Inspiration is where we look. Great night @northernstage to see @actingclassdoc with a 'diverse' q+a thanks to @AMarkCalvert @actorawareness

3:38 PM - 6 Feb 2018

6 Retweets 13 Likes O

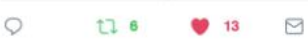

Tweets following a successful screening and Q\&A with the directors at The Northern Stage attended by around forty people.

\section{Conclusion}

The return of class as an important topic within the broader diversity agenda of the cultural industries is welcome and should be encouraged further, not least within film and television studies. While other diversity agendas are of course important, class speaks to the broader political economy of policy makers and their entrenched enmity against socialised access to cultural production and consumption. Meritocracy is the ideology of the elites that gives a progressive sheen to their discourse, concealing structural inequality and shifting the burden of risk and responsibility onto individuals. The creative industries generally and the acting industry specifically is very prone to internalising and reproducing the ideology of meritocracy with its trinity formula of hard work, talent and luck. If the latter term introduces 
some element of unfair random contingency, the disappearance of class privilege facilitated by the trinity formula, makes it effective as apologetics for the status quo. Our documentary film is a way of uncovering the real detrimental consequences of the situation and its impact on lives and hopes. In The Acting Class, the thematic arrangement of the voices and experiences of working-class origin actors (in the main) demonstrates that the struggles and risks are skewed, as are the rewards. These are, contra meritocracy, socially determined outcomes and the film as research provides a socialisation of those experiences. But it also demonstrates the reflective and analytical insights of the interviewees into their condition and thus provides a clue as to what resources are needed to change the situation. Those resources include awareness and organisation. The film begins with Tom Stocks, a working-class young man from Bolton who sets up a mutual-support network of working-class actors helping them to create, perform and train. Digital media technologies and social media were crucial in helping Tom get Actor Awareness launched, overcoming his initial starting deficit of having few contacts, little wider support and no money. If getting organised is a crucial part of social transformation, the film's creative-practice based methodology allowed it to also contribute to the organising capacity of the constituency it was speaking to. The campaign element of the research, for example in our collaboration with Equity, meant it became a form of praxis. Confronted with an ideology as tenacious and as important to the class stratified political economy of the UK as meritocracy is, the democratising potential of creative practice research has much to recommend it.

i. The Acting Class is available to watch free online at the film's website: www.theactingclass.info

ii. Methodological Note: We looked at the top 20 box office successes for UK qualifying films released in the UK over three years: 2014, 2015, and 2016. The list for the top 20 UK films in each year comes from the British Film Institute's annual statistical yearbook. The final sample of 58 (rather than 60) is due to two films being excluded from the sample: Antman, although a UK qualifying film had no British acting talent in a leading role. In the second case, Shaun the Sheep, it was not possible to ascertain the educational background of Justin Fletcher. In all cases the first British acting talent listed on each film's Wikipedia page was included in the sample. The educational background of the listed talent was then checked against their Wikipedia pages and where necessary additional sources such as newspaper articles. Simon Pegg was one of the few actors to have had both private and comprehensive 
school education. This makes his case ambiguous as it is not known how long he attended The King's School in Gloucester. In all other cases there appears to be a strong apartheid between those attending private and those attending state schools (including grammar schools).

\section{Bibliography}

Allen, K., Hollingworth, S. (2013) 'Sticky Subjects or "Cosmopolitan Creatives'? Social class, Place and Urban Young People's Aspirations for Work in the Knowledge Economy' Urban Studies 30 (3), pp.499-517.

Auerbach, C.F. and Silverstein, L. (2003) Qualitative Data, New York: New York University Press.

Banks, M., Hesmondhalgh, D. (2009) 'Looking for work in creative industries policy' International Journal of Cultural Policy, 15: 4, pp.415-430.

Belfiore, E. (2009) 'On bullshit in cultural policy practice and research: notes from the British case' International Journal of Cultural Policy 15 (3), pp.343-359.

BFI (2011) Opening our Eyes, How film contributes to the culture of the UK, British Film Institute.

Blackburn, R. (2018) 'The Corbyn Project' New Left Review May/June.

Blair, H. (2001) 'You're Only as good as Your Last Job': the Labour Process and Labour Market in the British Film Industry', Work, Employment \& Society, 15: 1, pp.149-169.

Blair, T. (2001) 'Britain Is On A Roll Whatever The Pop Stars Say, in Oakland, J (ed) Contemporary Britain, A Survey With Texts, London: Routledge.

Boltanski, L. and Chiapello, E (2018) The New Spirit of Capitalism, London: Verso.

Bourdieu, P. (1989) 'Social Space and Symbolic Power', Sociological Theory 7 (1), pp.1425.

Bourdieu, P. (2000) Pascalian Meditations, Translated by Richard Nice, Cambridge: Polity Press.

Busby, E.(2019) 'Nearly 800 public libraries closed since austerity launched in 2010' https://www.independent.co.uk/news/uk/home-news/library-closure-austerity-funding-cutsconservative-government-a9235561.html. Friday $6^{\text {th }}$ December.

Accessed Oct $22^{\text {nd }} 2020$.

Byrne, B. (2018) 'Qualitative interviewing' in Seale, C. (ed) Researching Society and Culture, London: Sage. 
Cantrell, T., Hogg, C. (2016) 'Returning to an old question: What do television actors do when they act?' Critical Studies in Television 11 (3) pp.283-298.

Cantrell, T (2018) 'Directing actors in continuing drama: Meaning-making and creative labour' Critical Studies in Television, 13 (3) pp.297-314.

Caughie, J. (2014) 'What Do Actors Do When They Act?' in Bignell J., Lacey S. (eds) British Television Drama, London: Palgrave and Macmillan.

Cultural Policy Collective (2004) Towards Cultural Democracy, Scottish Arts Council

Francis-Devine, B. (2020) 'Which ethnic groups are most affected by income inequality?' https://commonslibrary.parliament.uk/income-inequality-by-ethnic-group/ August 10 Accessed January $22^{\text {nd }} 2021$.

Friedman, S Laurison, D. (2019) The Class Ceiling. Why it pays to be Privileged, Bristol: Policy Press.

Friedman, S., O’Brien, D., Laurison, D., (2016) “"Like Skydiving without a Parachute": How Class Origin Shapes Occupational Trajectories in British Acting' Sociology, 51 (5), pp.992-1010.

Friedman, S., O'Brien, D. (2017) 'Resistance and Resignation: Responses to Typecasting in British Acting' Cultural Sociology, 11 (3), pp.359-376.

Hewett, R. (2015) 'The Changing Determinant of UK Television Acting' Critical Studies in Television Vol. 10 (1), pp.73-90.

Hogg, C (2020) 'A Class Act: An Interview with Julie Hesmondhalgh' Critical Studies in Television 13 (3) pp.302-311.

Kirby, P. (2016) Leading People 2016. The educational backgrounds of the UK professional elite. The Sutton Trust.

Labour Party (2017) Acting Up Report, Labour's inquiry into access and diversity in the performing arts.

Littler, J. (2018) Against Meritocracy, Culture, power and myths of mobility, Routledge, Abingdon.

Lubin, R. (2015) 'Merseyside writer Jimmy McGovern says it's a struggle to find workingclass actors’ Liverpool Echo http://www.liverpoolecho.co.uk/whats-on/filmnews/merseyside-writer-jimmy-mcgovern-says-8705725 24th Feb 2015.

Accessed July $5^{\text {th }} 2017$. 
Manstead, A. (2018) 'The psychology of social class: How socioeconomic status impacts thought, feelings and behaviour' The British Journal of Social Psychology, 57, pp.267-291.

McGuigan, J. (2009) Cool Capitalism, London: Pluto Press.

McGuigan, J. (2010) 'Creative labour, cultural work and individualisation' international Journal of Cultural Policy, 16:3, pp.323-335.

McRobbie, A. (2011) 'Rethinking Creative Economy as Radical Social Enterprise', Variant 41 (Spring).

Meiksins-Wood, E. (1998) The Retreat from Class, A New 'True’ Socialism, Verso 1998.

Milburn, A. (2014) Elitist Britain? Social Mobility and Child Poverty Commission, 2014.

Miller, T. (2009) 'From Creative to Cultural Industries' Cultural Studies 23:1, pp.88-99.

Oakley, K (2011) 'In its own image: New Labour and the cultural workforce,' Cultural trends, 20: 3-4, pp. 281-289.

O'Brien, D., Laurison, D., Miles, A., Friedman, S., (2016) 'Are the creative industries meritocratic? An analysis of the 2014 British Labour Force Survey', Cultural Trends, 25:2, pp.116-131.

O’Neill, D. (2018) Film as a Radical Pedagogic Tool Routledge New York

Neelands, J. (2015) Enriching Britain: Culture, Creativity and Growth, University of Warwick.

Newsinger, J. (2015) 'A Cultural shock doctrine? Austerity, the neoliberal state and the creative industries discourse’ Media, Culture \& Society, 37 (2), pp.302-313.

Ramaswamy, C. (2016) Welcome to the Dragon School - the lair of the British acting elite' in The Guardian, https://www.theguardian.com/education/shortcuts/2016/mar/28/dragonschool-tom-hiddleston-tom-hollander-hugh-laurie-night-manager March 28th, 2016. Accessed February $10^{\text {th }} 2021$.

Randle, K., Wing-Fai, L., Kurian, J. (2008) Creating Difference, Overcoming Barriers to Diversity in UK Film and Television Employment, Creative Industries Research and Consultancy Unit, University of Hertfordshire. Skillset/UK Film Council.

Reay, D. (2001) 'Finding or Losing Yourself? Working-class relationships to education' Journal of Education Policy 16 (4), pp.333-346.

Ross, A (2009) Nice Work If You Can Get It: Life and Labor in Precarious Times, New York: New York University Press. 
Savage, M (2015) Social Class in the $21^{\text {st }}$ Century, Pelican/Penguin London.

Tily, G. (2018) '17-year wage squeeze the worst in two hundred years'. https://www.tuc.org.uk/blogs/17-year-wage-squeeze-worst-two-hundred-years May 11th. Accessed November $11^{\text {th }} 2020$.

Wayne, M. (2006) 'Working Title Mark II: a critique of the Atlanticist paradigm for British cinema' International Journal of Media and Cultural Politics, 2 (1), pp.59-73.

Wayne, M. (2018) England's Discontents, Political Cultures and National Markets, Pluto Press, London.

Wayne, M. (2020) Marxism Goes To The Movies, Routledge, London. 